\title{
Qualitative and Quantitative Assessment of Water Resources of Aydar Arnasay Lakes System (AALS)
}

\author{
Rashid Kulmatov ${ }^{1}$, Nodirbek Mullabaev ${ }^{2}$, Asqar Nigmatov ${ }^{1}$, Dilafruz Kulmatova ${ }^{1}$, Jobir Sobirov ${ }^{2}$ \\ ${ }^{1}$ Department of Applied Ecology, National University of Uzbekistan, Tashkent, Uzbekistan \\ ${ }^{2}$ Laboratory of Hydrobiology and Ichthyology, Institute of Genofund of Flora and Fauna, \\ Uzbekistan Academy of Sciences, Tashkent, Uzbekistan \\ Email: rashidkulmatov@yahoo.com
}

Received July 31, 2013; revised September 2, 2013; accepted September 24, 2013

Copyright (C) 2013 Rashid Kulmatov et al. This is an open access article distributed under the Creative Commons Attribution License, which permits unrestricted use, distribution, and reproduction in any medium, provided the original work is properly cited.

\begin{abstract}
The Aydar Arnasay Lakes System (AALS) is an artificial lake system which was created in 1969 by diverting flood water from Chardarya reservoir. It has developed into a wetland of $4000 \mathrm{~km}^{2}$ area recognized by the Ramsar Convention as of global importance. It is not only a refuge for birds and wildlife but also has seen the emergence of fishery and tourism since. Understanding of its behavior with respect to the quantitative and qualitative aspects of water resources is important for future use and management, especially for further development of fishery and ecotourism. The factors influencing changes in quantity and quality of AALS water were studied between 1993 and 2011. Starting from 1993 the water level and water volume of the lake progressively increased. The spatio-temporal distributions of $\mathrm{pH}$, dissolved oxygen, ammonium, nitrite, nitrate, phosphate, chloride, and biochemical oxygen demand (BOD5) during 2003-2005 and 2009-2011 were determined. On the basis of the conducted hydrological and hydro-chemical research fishery development in AALS is recommended. The question is posed what requirements have to be in met in the future in order to guarantee the prolonged existence of the lake at a suitable water quality.
\end{abstract}

Keywords: Aydarkul-Arnasay Lakes System (AALS); Water Quality; Quantitative Assessment; Hydrology; Fishery

\section{Introduction}

Aydarkul Arnasay Lakes System (AALS) is the largest artificial lake system in the Aral Sea basin. AALS consists of three brackish lakes: Arnasay, Aydarkul and Tuzkan. It is located in the Arnasay saline depressions of the south-eastern Kyzylkum in the territory of Uzbekistan [1]. The history of AALS may be divided into two principal periods: the first until 1969 and the second period after 1969. During the first period AALS could not be found on the map. There were only 3 natural depresssions, containing saline water originating from ground water and precipitation: Arnasay, Aydar and Tuzkan. Tuzkan means "Salt source" which derives from the fact that until 1969 local people harvested salt from this lake and used it as table salt. AALS is the unintentional by-product of Soviet planning. In the 1965 the Syrdarya was dammed up and the Chardarya irrigation dam was constructed at the same time. Floodgates were constructed for flood control. During the 1960's, the Soviet Union began the development of new desert lands (Golodniy Steppe) on the right bank of the Syrdarya river for cultivation of cotton on the territory of Uzbekistan. Polluted collector drainage water (CDW) was diverted via the Central Golodnostep Collector (CGC) into the Eastern Arnasay depression. So, at the end of 1960 there were several small lakes connected via channels carrying CDW.

The second period began when this natural depression was filled in 1969 with water originating from a devastating flood season. Due to limited capacity of the siltedup Syrdarya river channel below Chardara reservoir (on the border between Kazakhstan and Uzbekistan), excess volumes of water have since been discharged into Arnasay lake during high water years. Between February 1969 and February 1970, about $60 \%$ of the Syrdarya's average annual water flow (about $21 \mathrm{~km}^{3}$ ) was diverted from Chardarya Reservoir into the Arnasay lowland to accommodate inadequacies of the dam [1,2]. Thus, since 1969 Aydarkul Lake regularly received water from Syrdarya River whenever its flow exceeded the capacity of Chardarya Reservoir.

In the last few years, release of water from the NarynSyrdarya hydroelectric power station has also been 
common in winter. Since 1992, Toktogul reservoir has been used to generate more electricity during winter months, leading to a significant increase of the volume of water in the AALS [3]. This has gradually filled up the natural cavity of Arnasay lowland creating the second largest lake in the region. In addition to fauna common in Kyzylkum, there are many species of water birds migrating from the Aral Sea which make their homes around the lake. The shores provide habitats of brush and swampy thickets to pheasants, wild boars, jackals, badgers, steppe cats and other animals. In 2008, AALS was included in the Ramsar list of wetlands of global importance which has increased its visibility worldwide. According to ecologists, the inclusion of AALS in the Ramsar list should draw attention of the world community to the problem of preservation and improvement of ecological conditions of this unique lake ecosystem, the sustainable future of which is not guaranteed. The AALS is located at considerable distance from inhabited localities. At present, 345 families (approx. 1760 people) reside near the lake. AALS region provides a great potential for fishing, hunting and ecological tourism activities.

Unfortunately, many publications used today, contain incomplete or out-of-date information. The major part of research work carried out by local scientists focuses on quality and in some cases on quantity [2-6]. In particular, the salt composition of water and the water balance of AALS in 1970 were studied in $[4,5]$. The pastures along AALS for the purpose of management of water-land resources and vegetation around lakes are mapped, particularly in view of increasing the income of rural cattle breeders [6]. In this work, the assessment of water levels in AALS through satellite images used by Kurbanov et al. [7]. Wahyuni et al. [8] investigated the water level fluctuation in AALS, and its impact on the surrounding groundwater level. A positive correlation between the increasing water surface area as a function of water level and the groundwater level was found [8].

Today AALS is the largest fish supply reservoir in the country. After the termination of fish production in Aral sea, big attention was given to fishery development in internal reservoirs and piscicultural industry in general. Many species of fish, including Cyprinus caprio, Stizostedion lucioperca, Abramis brama, Silurus glanis, Aspius aspius, Pelecus cultratus, Channa argus were introduced in AALS, which are a resource of industrial fishing now. The AALS provides 760 to 2000 tons of fish annually (according to statistical data between 1994 and 2005) $[1,3]$. Therefore local scientists explored the possibility of further fishery development in AALS [9-14].

At the moment, AALS has a major impact on the ecological, social, and economic situation and is of strategic importance for Uzbekistan and Kazakhstan. Yet, its sus- tained existence in the long term is not guaranteed. The question has to be asked what size of lake is recommended to preserve in the future and what inflows with respect to quantity and quality are associated with it, in order not to repeat the tragedy of the Aral Sea.

\section{Study Area}

The AALS is located in the south-eastern part of Uzbekistan on the territory of Navoi and Dzhizak provinces (Figure 1).

This area is included in the northern and northwestern parts of the Golodnoy Steppe and forms the border between the Golodnoy Steppe and the Kyzyl-Kum desert. The Aydar-Arnasay lakes system is composed of Aydarkul, Tuzkan, Arnasay lakes and the surrounding desert areas (Figure 2).

The climate of Arnasay depression area is continental, arid and semiarid. Winter is short and moist, with an unstable snow cover. The average annual air temperature varies from $13.2^{\circ} \mathrm{C}$ (in the west) to $14.4^{\circ} \mathrm{C}$ (in the south). During the hottest time (July-August) the temperature reaches $29.4^{\circ} \mathrm{C}-42.7^{\circ} \mathrm{C}$. Water warms up to $28^{\circ} \mathrm{C}-30^{\circ} \mathrm{C}$. In the coldest months the water temperature decreases to $3.6^{\circ} \mathrm{C}[12,15]$. Given the desert environment, the shallow lakes are characterized by high evaporation especially in summer, when maximum water temperature approaches $30^{\circ} \mathrm{C}$. One objective of this study is to inspect the quantitative, qualitative and hydrological water parameters of Aydar Arnasay lake system (AALS) during 2003-2005

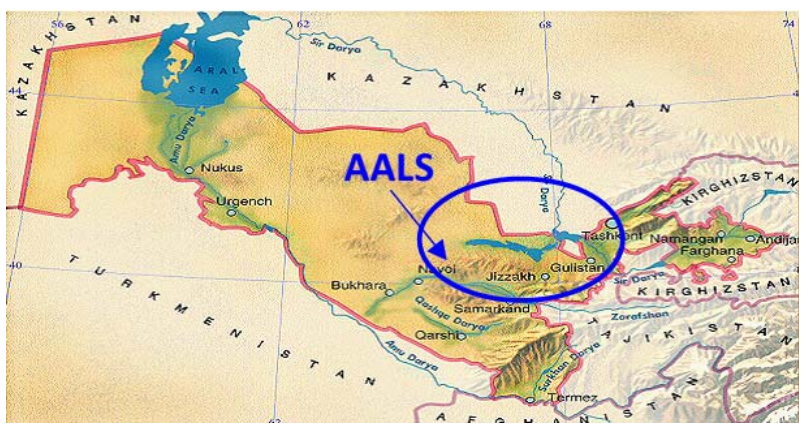

Figure 1. Map of study area.

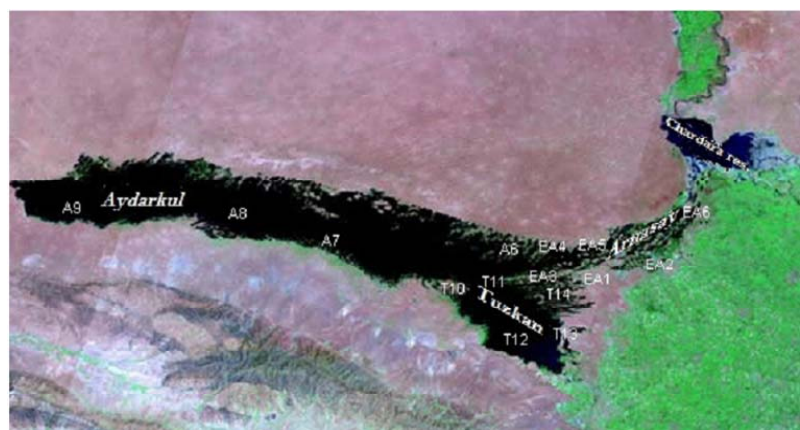

Figure 2. Satellite view of AALS, September 2012 [3]. 
and 2010-2011 from the fishery development and ecotourism points of view.

AALS is located far from settled areas which causes certain difficulties in carrying out regular scientific research expeditions. In this article, results of field and laboratory research carried out in 2003-2005 and 20102011 are presented. Sampling points were chosen such that they reflect the hydrological and hydrochemical regimes of the lakes relevant for fishery. The water samples collected were analyzed at the laboratory of the Hydrometeorological Research Institute (NIGMI) in Tashkent, Uzbekistan, using standard analysis methods [16]. The following parameters were determined: $\mathrm{pH}$, dissolved oxygen, ammonium, nitrite, nitrate, phosphate, chloride, biochemical oxygen demand (BOD5), chemical oxygen demand (COD) and heavy metals. Some restricted numbers of samples were analyzed to obtain total suspended solids both in 2005 and 2010-2011. pH, turbidity, and dissolved oxygen were determined directly at the sampling point using portable instruments [16].

\section{Results and Discussion}

\subsection{Hydrological conditions of AALS}

Regarding the water balance, the inflow components of AALS include the river water coming from Chardara reservoir, the collector drainage waters (CDW) discharged from irrigated lands, groundwater infiltration and precipitation on the water surface of the lakes. The outgoing part of the AALS water balance consists of evaporation, water which is used for irrigation of adjoining agricultural areas and underground outflow from the lake system. The Arnasay depression is a natural drain and receiver of collector-drainage waters from irrigated lands of Golodnoy steppe (Syrdarya) and Dzhizak provinces. The discharges to the collectors are not uniformly distributed. The three main collectors Central Golodnostep Collector (CGC), Akbulak and Kli account for more than $97 \%$ of total volume of drainage water discharged to AALS annually (Table 1). The annual total discharge of CDW to AALS between 2005 and 2010 stabilized at a level of $2.0-2.7 \mathrm{~km}^{3} / \mathrm{a}$.

The mineralization of CDW is considerably lower than the mineralization of the bulk water of AALS. Yet, these

Table 1. Annual discharge of the main collectors in AALS, in $10^{6} \mathrm{~m}^{3} / \mathrm{a}$.

\begin{tabular}{ccccccc}
\hline Collectors/Year & $\mathbf{2 0 0 5}$ & $\mathbf{2 0 0 6}$ & $\mathbf{2 0 0 7}$ & $\mathbf{2 0 0 8}$ & $\mathbf{2 0 0 9}$ & $\mathbf{2 0 1 0}$ \\
\hline CGC & 1220 & 1509 & 1446 & 1124 & 1974 & 2208 \\
Akbulak & 195 & 212 & 183 & 133 & 118 & 132 \\
Kli & 526 & 436 & 390 & 308 & 340 & 348 \\
Total discharge & 1941 & 2157 & 2019 & 1565 & 2433 & 2688 \\
\hline
\end{tabular}

waters play a role in governing the salinity regime of AALS water (Table 2).

The Central Golodnostep Collector (CGC) drainage water has a higher mineralization compared to Kli and Akbulak as shown in Table 2. According to data from Uzgidromet, precipitation contributes only a small part to the water balance of the lakes. The average annual precipitation is $200 \mathrm{~mm}$. This amounts to about 360 mio $\cdot \mathrm{m}^{3} / \mathrm{a}$ on the lake area and accounts for about $14 \%$ of the water input to the lakes $[3,15]$. The regime of groundwater inflow depends on the regime of water levels of the lakes. Expected stabilization of the levels of the lakes will lead to a constant groundwater inflow the volume of which according to Uzgidromet estimates amounts to 40 - $50 \mathrm{mio} \cdot \mathrm{m}^{3} / \mathrm{a}$ [3]. Shallow lakes like AALS, located in an arid zone where the maximum summer temperature of water reaches $30^{\circ} \mathrm{C}$ are characterized by high evaporation. High temperature, especially in summer time, and the vicinity to the desert with low humidity of air promotes the increased evaporation. Studies by scientists of NIGMI show that the magnitude of evaporation depends on the morphology of the depressions, leading to shallow and deep-water areas, and varies between $1100 \mathrm{~mm} / \mathrm{a}$ (for the eastern reach of lake Aydarkul) and $1400 \mathrm{~mm} / \mathrm{a}$ (for the Eastern Arnasay lakes) [3,12].

Besides evaporation from the open water surface, transpiration makes a large contribution to water losses. It depends on meteorological conditions, type, height and density of vegetation. Output by evaporation from the water surface is estimated to account for $86 \%$ of total evapotranspiration; the transpiration by water vegetation is thought to contribute $14 \%[3,12]$. The average annual evaporation for the whole lake system is accepted to be $1200 \mathrm{~mm}$. Nowadays water evaporates from the lake surface at an estimated rate of $3.8-4.2 \mathrm{~km}^{3} / \mathrm{a}$ (Table 3 ). The high mineralization of water in the lakes of $5-7 \mathrm{~g} / \mathrm{L}$ practically does not yet affect the intensity of evaporation.

Water for irrigation of adjoining territories is withdrawn from the Arnasay reservoir. Therefore while compiling the annual water balance of the lake system, the volume of water used for irrigation was also considered. The total water withdrawal for irrigation in the period

Table 2. Annually averaged mineralization of the main collectors $(\mathrm{g} / \mathrm{L})$.

\begin{tabular}{ccccccc}
\hline Collectors/Year & $\mathbf{2 0 0 5}$ & $\mathbf{2 0 0 6}$ & $\mathbf{2 0 0 7}$ & $\mathbf{2 0 0 8}$ & $\mathbf{2 0 0 9}$ & $\mathbf{2 0 1 0}$ \\
\hline CGC & 4.50 & 4.78 & 4.35 & 5.68 & 6.40 & 4.86 \\
Akbulak & 2.64 & 2.34 & 4.06 & 3.09 & 3.74 & 3.30 \\
Kli & 2.38 & 2.35 & 3.43 & 2.03 & 2.84 & 2.63 \\
Weighted average & 3.74 & 4.05 & 4.15 & 4.74 & 5.77 & 4.49 \\
\hline
\end{tabular}


Table 3. Annual amount of losses by evaporation, $\mathrm{mio}^{\circ} \mathrm{m}^{3} / \mathrm{a}$.

\begin{tabular}{cccccccccccc}
\hline Year & $\mathbf{2 0 0 0}$ & $\mathbf{2 0 0 1}$ & $\mathbf{2 0 0 2}$ & $\mathbf{2 0 0 3}$ & $\mathbf{2 0 0 4}$ & $\mathbf{2 0 0 5}$ & $\mathbf{2 0 0 6}$ & $\mathbf{2 0 0 7}$ & $\mathbf{2 0 0 8}$ & $\mathbf{2 0 0 9}$ & $\mathbf{2 0 1 0}$ \\
\hline Area, $\mathrm{km}^{2}$ & 3142 & 3129 & 3099 & 3257 & 3468 & 3565 & 3569 & 3520 & 3469 & 3419 & 3505 \\
Evaporation & 3770 & 3755 & 3718 & 3909 & 4161 & 4278 & 4282 & 4224 & 4163 & 4103 & 4206 \\
\hline
\end{tabular}

from 2000 to 2010 amounts to $150 \mathrm{mio} \cdot \mathrm{m}^{3} / \mathrm{a}$ on the average [3]. Outflow of groundwater from the lake system, as well as inflow of groundwater to the numerous lakes, is very insignificant in size compared with other components of the water balance (inflow of rivers and drainage water, evaporation). Further, they cancel out approximately over time. Therefore, in balance calculations they are accepted to be identical in size and equal to 50 $\operatorname{mio} \cdot \mathrm{m}^{3} / \mathrm{a}[3,12]$. The groundwater level data in the neighborhood of the lakes and the inundation maps of the lakes for the past years were obtained from the Research Institute of Hydrometeorology of Uzbekistan [3].

High water levels in AALS are one of the problems threatening the social and environmental situation around AALS. The increase in water level has resulted in flooding of large areas of farmland in Djizak province. Figure 3 shows the dependence of the water volume in AALS from superficial inflow. The basic source of water inflow is from Chardara reservoir. Another important source of inflow is CDW from nearby agricultural fields. From 1993 to 2010 AALS has received more than $38 \mathrm{~km}^{3}$ of water from Chardara reservoir. In 1994, the discharge of excess water from Chardara Reservoir reached the maximum value of more than $9 \mathrm{~km}^{3}$. Very small discharges from Chardara reservoir were observed in 2001 and 2006 - 2009 (Figure 3).

It is necessary to consider one important factor: if annual discharges from Chardara reservoir were stopped, the water level in AALS would begin to drop because the annual inflow of CDW $2.5-2.7 \mathrm{~km}^{3}$ is less than the annual volume of evaporation from the lake surface. The inflow in 1994 was the highest in the 18 -year period 1993-2010 (Figure 3). The hydrological regime of AALS was unstable in the period 1993-2010 because of large variations in the discharge of water from Chardara reservoir.

The variations in water volume and the inflow water level of the AALS from 1993 to 2010 are shown in Figure 4. Before 1991, the annual increase in water level varied between $0.01 \mathrm{~m}-0.24 \mathrm{~m}$ [3]. Starting from 1993 to 2010 , the water level, water surface area, and water volume of the lake progressively increased because of high discharges from Chardara reservoir. The water level has been fluctuating within $0.1-2.9 \mathrm{~m} / \mathrm{a}$ and has been causing overall increases in water surface area of AALS. The increase of AALS water level was observed within

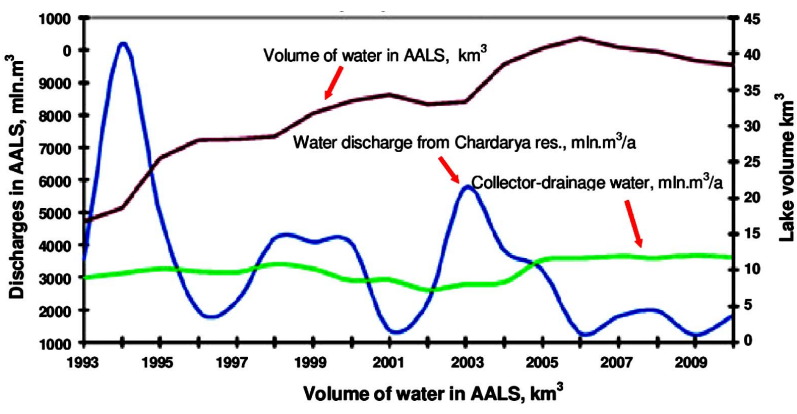

Figure 3. Dependence of AALS water volume on superficial inflow.

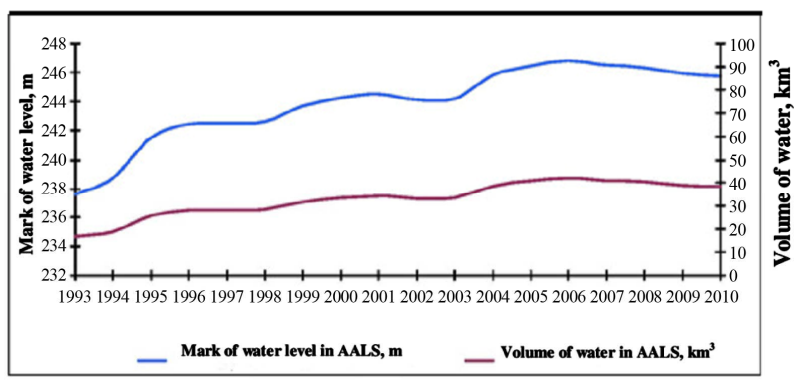

Figure 4. Water level change in AALS during 1993-2010.

the period of 1993 to 2010 and within this period the area increased from $3039 \mathrm{~km}^{2}$ to $3748 \mathrm{~km}^{2}$.

Today the volume of water resources of AALS is 40 $42 \mathrm{~km}^{3}$ and the area equals $4000 \mathrm{~km}^{2}$. It is nearly $250 \mathrm{~km}$ long and up to $25 \mathrm{~km}$ wide. The AALS occupies a significant area of the fertile land (more than 100 mio. ha) which was used as pasture in earlier times. It results in significant evaporation that is producing the development of a local "greenhouse effect". The increase in water level of AALS induced flooding of rangelands, allocated for livestock grazing [7]. The most serious problem occurs in Dzhizak region (one of the provinces in Uzbekistan). The increase in AALS surface water level is followed by intensive evaporation in summer time which induces changes in water quality and ion mineral composition of both surface and groundwater.

Figure 5 shows the change in volume and area of the AALS from 1970-2005. In Figure 5 data for 1970 are obtained from [5], data for 1990 are obtained from [2] while the data for 2005 are our own. Because water was not released from Chardara reservoir in 1990 the volume of the AALS decreased to $14 \mathrm{~km}^{3}$ and the area to 1800 $\mathrm{km}^{2}$. 


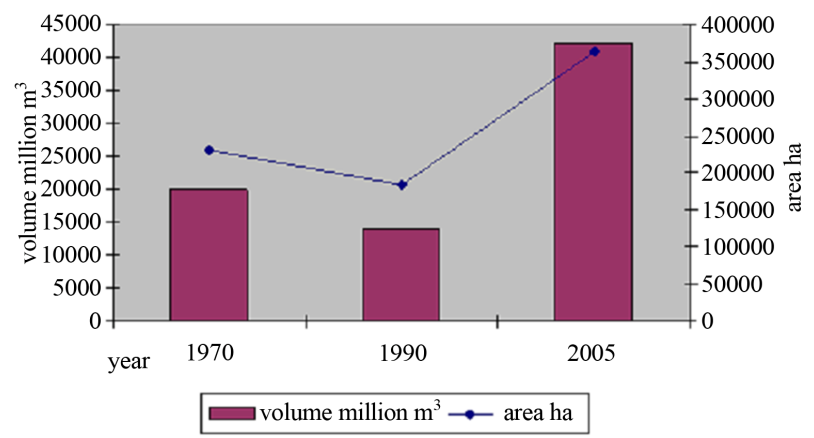

Figure 5. Changes in volume and area of the AALS since 1970.

\subsection{Hydro-Chemical Regime of AALS}

Results of basic investigations in 2003-2005 and supplementary investigations in 2009-2011 are presented. The schedule of conducted field work is given in Table 4 . The water samples from the AALS in 2003-2005 were taken during the spring, summer and fall seasons of the year. Supplementary investigations were carried out in 2009-2010 for $\mathrm{pH}$, DO and BOD and in 2011 for main ions, nutrients and heavy metals.

In the winter season water samples were taken only in 2003 because of the freezing of the AALS in other years. The map of water sampling sites in Table 5 is shown in Figure 2. In Table 5 detailed descriptions of water sampling sites on the AALS are given.

Water samples were taken in different parts of the eastern Arnasay, Tuzkan, and Aydar lakes, and the CGC (Eastern part, channel and western part, confluence of Lake Tuzkan). Sampling sites for the analysis were selected in a way that they fully reflect the hydrochemical mode and quality of water. The items analyzed are the most important from the fishery point of view.

\subsection{1. pH and COD}

According to data obtained in the field trips, $\mathrm{pH}$ varied within the interval $6.6-8.8$ (Table 6). It is within the ecologically permissible level. In the AALS at the station of the Eastern Arnasay pH values fluctuated within 7.2 $8.3 \mathrm{pH}$ decreased in winter while during the rest of the year it stayed more or less constant. The decrease in $\mathrm{pH}$ values is associated with the reduction of photosynthesis in the winter season as algae do not use free carbonic acid, and as a result the concentrations of $\mathrm{CO}_{2}$ and $\mathrm{H}_{2} \mathrm{CO}_{3}$ increase. The $\mathrm{pH}$ in the AALS is suitable for fishery development.

\subsubsection{Dissolved Oxygen}

The average values of dissolved oxygen in AALS water varied over different seasons of the year probably due to algal activity (Figure 6).

The dissolved oxygen and BOD values found in the

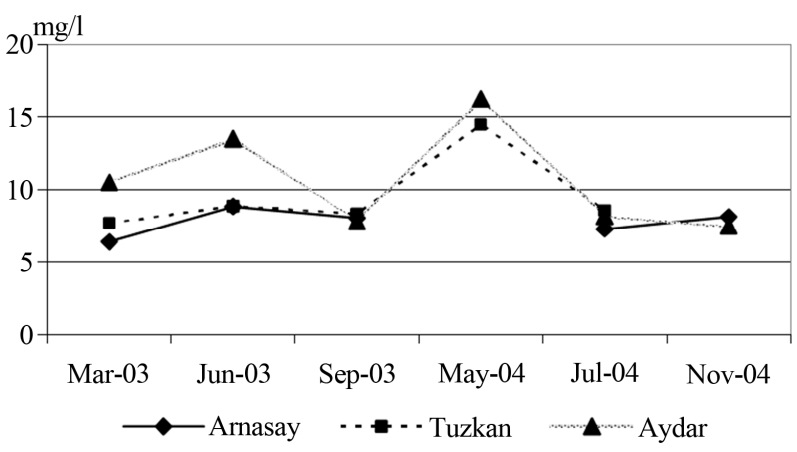

Figure 6. Contents of dissolved oxygen in the water AALS.

Table 4. The schedule of conducted research in the AALS.

\begin{tabular}{cccc}
\hline Year & Spring & Summer & Fall \\
\hline 2003 & March & June & September \\
2004 & May & July & November \\
2005 & April & August & September \\
2009 & September & September & September \\
2010 & April & April & April \\
2011 & April & April & April \\
\hline
\end{tabular}

Table 5. Sampling sites in the AALS.

\begin{tabular}{|c|c|c|}
\hline Location & Reach & $\begin{array}{c}\text { Sampling } \\
\text { points }\end{array}$ \\
\hline \multirow{7}{*}{ Eastern Arnasay } & Southeast, south-east littoral & $\mathrm{EA}^{*}$ \\
\hline & Southeast, littoral, open flat water & EA4 ${ }^{*}$ \\
\hline & Southeast in front of dam & EA5 \\
\hline & East, the left like site & EA6 \\
\hline & East, channel & EA7 \\
\hline & North western part & $\mathrm{T} 10^{*}$ \\
\hline & North western part, open reach & $\mathrm{T} 11$ \\
\hline \multirow[t]{5}{*}{ Tuzkan } & Southern part & $\mathrm{T} 12$ \\
\hline & Southeastern part & $\mathrm{T} 13$ \\
\hline & Eastern part & $\mathrm{T} 14^{*}$ \\
\hline & Eastern part & A6 \\
\hline & Eastern part, open reach & $\mathrm{A} 7^{*}$ \\
\hline \multirow[t]{2}{*}{ Aydar } & Southern part & $\mathrm{A} 8^{*}$ \\
\hline & Central part & A9 \\
\hline Central & Eastern part, channel & EA2 \\
\hline $\begin{array}{l}\text { Golodnostepskiy } \\
\text { Collector (CGC) }\end{array}$ & Western part, confluence of lake Tuzkan & EA1 \\
\hline
\end{tabular}

2009-2010 campaign are given in Table 7. Samples were taken in winter 2009 and spring 2010. They are comparable to the basic data found before. 
Table 6. Values of pH in AALS.

\begin{tabular}{cccccccccc}
\hline Lakes & Spring & Summer & Autumn & Spring & Summer & Autumn & Spring & $\begin{array}{c}\text { Autumn } \\
\mathbf{2 0 0 9}\end{array}$ & $\begin{array}{c}\text { Spring } \\
\mathbf{2 0 1 0}\end{array}$ \\
\hline Eastern Arnasay & 8.3 & 7.9 & 7.4 & 7.2 & 7.9 & 8.0 & 8.2 & 9.02 & 7.07 \\
Tuzkan & 8.9 & 7.9 & 7.5 & 7.3 & 8.1 & 7.8 & 7.7 & 8.01 & - \\
Aydar & 8.9 & 7.7 & 7.6 & 7.5 & 6.6 & 7.7 & 7.9 & 7.70 & - \\
\hline
\end{tabular}

Table 7. The physical and chemical parameters of AALS water.

\begin{tabular}{cccc}
\hline Selection place of samples & Date & $\begin{array}{c}\mathrm{O}_{2} \\
(\mathrm{mg} / \mathrm{l})\end{array}$ & $\begin{array}{c}\mathrm{BOD}_{5}, \\
\left(\mathrm{mg} \mathrm{O}_{2} / \mathrm{l}\right)\end{array}$ \\
\hline E. Arnasay & 22.09 .2009 & 9.22 & 1.10 \\
Tuzkan & 22.09 .2009 & 8.01 & 1.38 \\
Aydar & 22.09 .2009 & 7.70 & 1.54 \\
E. Arnasay & 21.04 .2010 & 7.38 & 3.13 \\
\hline
\end{tabular}

\subsubsection{Mineralization of AALS Water}

Mineralization (total dissolved solids) is one of the most important parameters to measure for determining contamination of the lakes. The hydrologic situations of AALS cause an unequal mineralization in different parts of the lakes. In Arnasay lake water has low salinity due to its geomorphology and is used for irrigation of agriculture land. The water of Aydarkul and Tuzkan has comparatively high mineralizion because of addition of saline wastewater coming from the irrigated fields [3]. Rather low mineralization in Arnasay lake in the spring $(4-5 \mathrm{~g} / \mathrm{L})$, and higher concentrations in the summer $(5.8$ $\mathrm{g} / \mathrm{L})$ of 2003 is connected with discharges of lower mineralized flood waters from Chardara reservoir (Figure 7). Chardara reservoir collects Sirdarya water having a low mineralization of $1.5-2.0 \mathrm{~g} / \mathrm{L}$ [16].

\subsubsection{Nutrients}

One of the major ecological factors of for fish development is the nutrient level of lakes and reservoirs. Development of primary producers in water ecosystems is defined, first of all, by the availability of nutrients.

Ammonium. The maximum allowable concentrations (MAC) value for ammonium is $0.39 \mathrm{mg} \mathrm{N} / \mathrm{L}$. The increase of ammonium ion concentration can be used as a quality indicator of sanitary conditions of a water body. It reflects the deterioration of the sanitary state of the reservoir and the impact of pollution from household wastewater and agricultural drains. As shown in Figure 8, the concentration of ammonium nitrogen in the AALS fluctuates from zero to $0.12 \mathrm{mg} / \mathrm{L}$. The maximum concentration of ammonium nitrogen of $0.12 \mathrm{mg} / \mathrm{L}$ was observed in winter period 2003-2004. In summer 2003, the increase in ammonium nitrogen concentrations was observed in all of the AALS. Also rather high ammonium

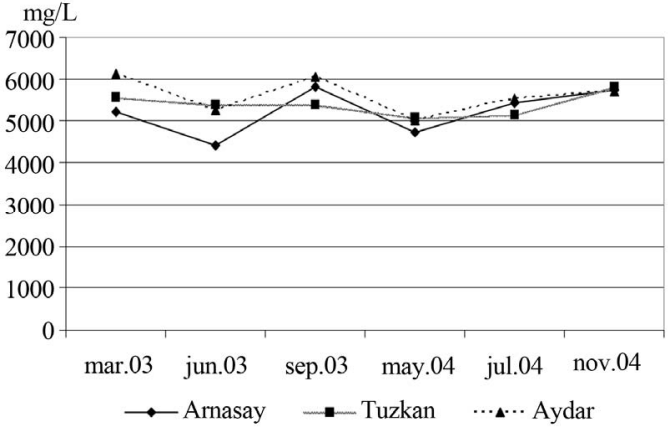

Figure 7. Dynamics of changing mineralization of water in the AALS.

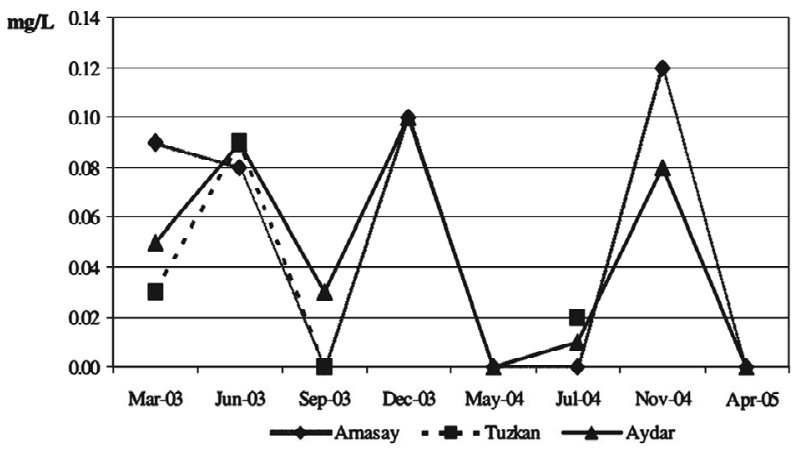

Figure 8. Variation in concentration of ammonium.

concentration in the winters of 2003-2004 was noted. The ammonium minimum concentrations for the autumn and spring season samples 2003-2005.

Nitrite nitrogen. The analysis of nitrite concentrations in the AALS water is important because the MAC of for nitrites is low $(0.05 \mathrm{mg} \mathrm{N} / \mathrm{L}$ for fishery, $0.02 \mathrm{mg} \mathrm{N} / \mathrm{L}$ for potable water), and may show early signs of water quality deterioration. The concentration of nitrites in the AALS fluctuated from 0.001 to $0.04 \mathrm{mg} / \mathrm{L}$ and was low during the vegetative period, which is in spring (Figure 9). The maximum nitrite nitrogen concentration was observed to be $0.04 \mathrm{mg} / \mathrm{L}$ in Arnasay Lake during spring 2005.

Nitrate nitrogen. In Uzbekistan, the MAC value for $\mathrm{NO}_{3}$ is $45 \mathrm{mg} \mathrm{NO} / \mathrm{L}$. The nitrate contents in the AALS fluctuate during different seasons of year (Figure 10). They are generally low. An increase of nitrate concentration in the spring is connected to leaching of nitrate by rains from soil. Thus, the basic source of nitrate entering 


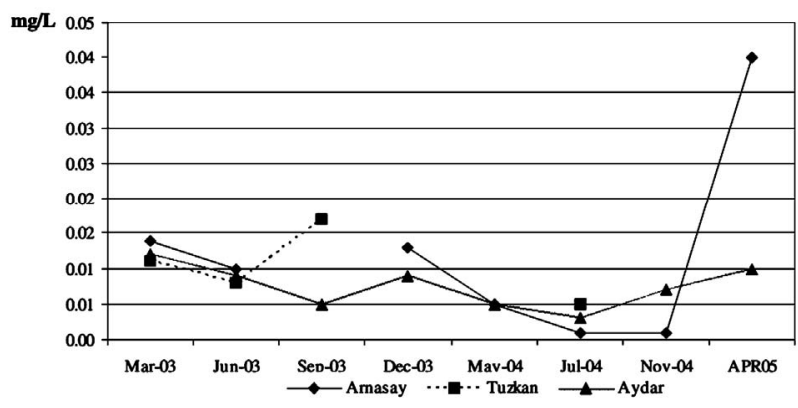

Figure 9. Dynamics of nitrite nitrogen concentrations in AALS.

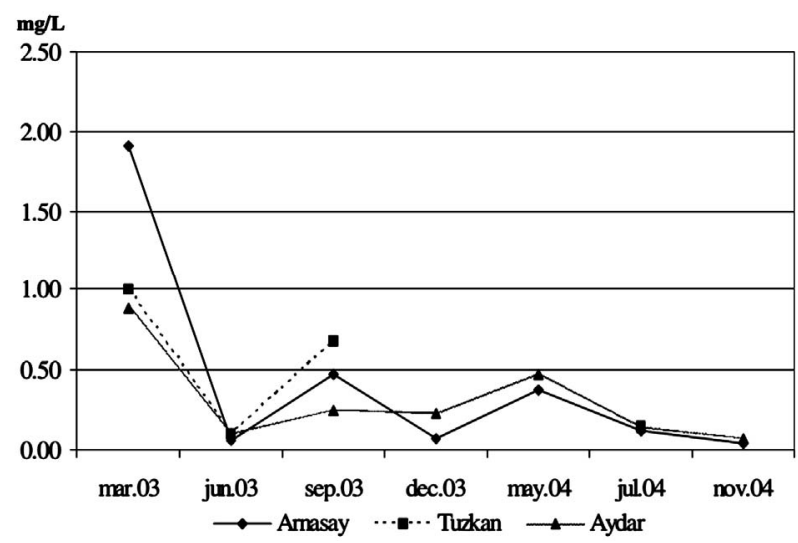

Figure 10. Dynamics of changing contents of nitrate nitrogen in the water of AALS.

surface waters is the irrigated soil cover. In Uzbekistan nitrogen fertilizers are widely used for cultivation of cotton, wheat and other crops [1]. The summer minimum of nitrate concentrations corresponds to the period of vigorous development of water plants and phytoplankton which is accompanied by uptake of nitrogen.

Phosphate. The phosphate concentration rises in autumn and decreases in summer (Figure 11). Such trends were especially clear in the Aydar and the Tuzkan lakes.

In the case of Aydar and Tuzkan lakes phosphates contents showed a decrease during the summer and an increase during the autumn. On the whole, in the AALS the phosphorus contents during the summer period decreased, which is possibly connected with the plentiful development of phytoplankton. Phosporous is the limiting nutrient for algal growth in the lake system according to the Redfield ratio.

Silica. The silica contents changed within the range of $0.68-1.78 \mathrm{mg} / \mathrm{L}$ for the investigated period. Rather low concentration of silica in the summers of 2003-2004 was noted. Silica concentration was relatively high in Aydar lake and lower in Arnasay. During the investigation period, silica in the Tuzkan Lake was only observed in spring 2003, autumn 2003, and spring 2004. Silica contents were higher in the spring and winter and compara-

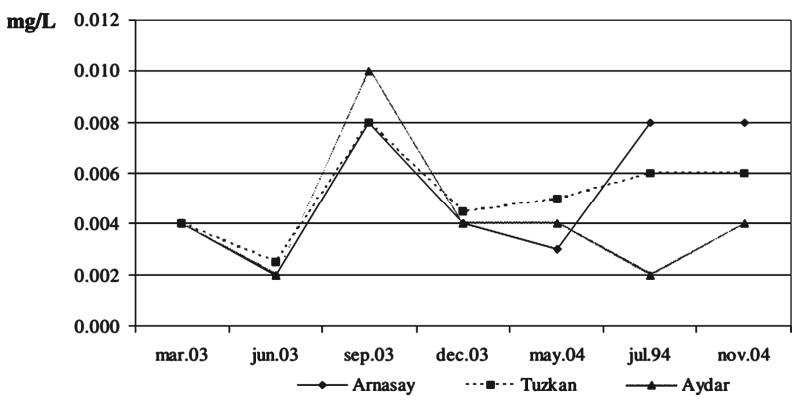

Figure 11. Dynamics of changing concentrations of the general phosphate in AALS water.

tively lower in the summer seasons (Figure 12).

Fluorine. The MAC level of fluorine is $0.75 \mathrm{mg} / \mathrm{L}$ in Uzbekistan. Concentrations of fluorine in different parts of the AALS water fluctuate between 0.24 and $0.85 \mathrm{mg} / \mathrm{L}$ uniformly. Concentration of fluorine was observed in all three lakes (Figure 13). Higher values of the $\mathrm{pH}$ promote increased mobility of fluorine. It is known that phosphate fertilizer contains fluorine as a residual element [1]. Phosphate fertilizers are widely used in agriculture, and are sources of pollution of river and lake water by fluorine. On the whole, the concentration of fluorine did not exceed the MAC value.

Heavy metals. Heavy metals (HMs) in the river and lake waters are present in different physical and chemical forms [17]. The dissolved forms of heavy metals are more toxic than are undissolved forms of HMs. Uzbekistan's national water quality standard estimates jointly both total metal concentrations in MAC values.

Zinc. The MAC value is $0.01 \mathrm{mg} / \mathrm{L}$ in Uzbekistan. During 2003 in the AALS some differences in the zinc concentration were observed. Zinc concentration increased in Arnasay lake to $0.075 \mathrm{mg} / \mathrm{L}$ during the autumn period of 2003 (Figure 14). In spring and autumn of 2003, the concentration of zinc was about $0.005 \mathrm{mg} / \mathrm{L}$. This is extremely low and it was identical in Arnasay and Aydar Lakes. In autumn 2003, the concentrations of zinc were very different in Arnasay, Aydar, and Tuzkan Lakes. Their values were recorded as $0.043 \mathrm{mg} / \mathrm{L}, 0.056$ $\mathrm{mg} / \mathrm{L}$ and $0.074 \mathrm{mg} / \mathrm{L}$ respectively.

In the East Arnasay the zinc concentration increased on average to $0.043 \mathrm{mg} / \mathrm{L}$, in lake Tuzkan to $0.074 \mathrm{mg} / \mathrm{L}$, and in lake Aydar to $0.056 \mathrm{mg} / \mathrm{L}$ in the autumn of 2003 (Figure 14). During the other periods, the zinc concentration fluctuated significantly, and was considerably lower than the maximum concentration limit for fish development reservoirs $(0.01 \mathrm{mg} / \mathrm{L})$.

Copper. In the AALS, the dynamics of the copper concentration increased during the spring periods of 2003-2004. During the spring period of 2003 the maximum copper concentration was $0.0085 \mathrm{mg} / \mathrm{L}$ in the east Arnasay (Figure 15). Comparatively lower copper con- 


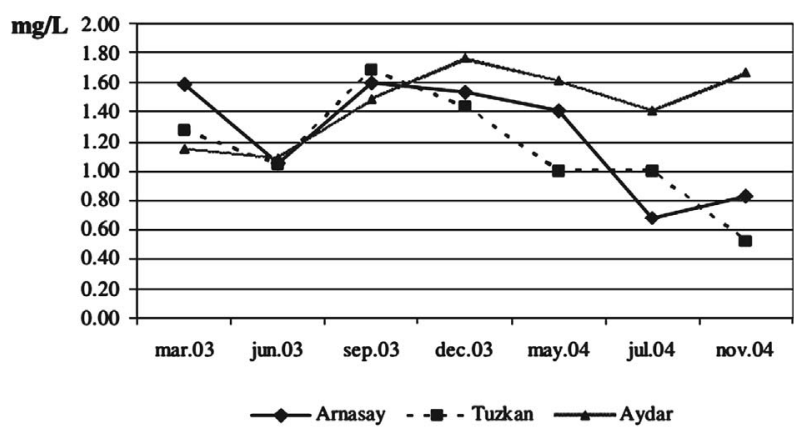

Figure 12. Dynamics of changing concentrations of silica.

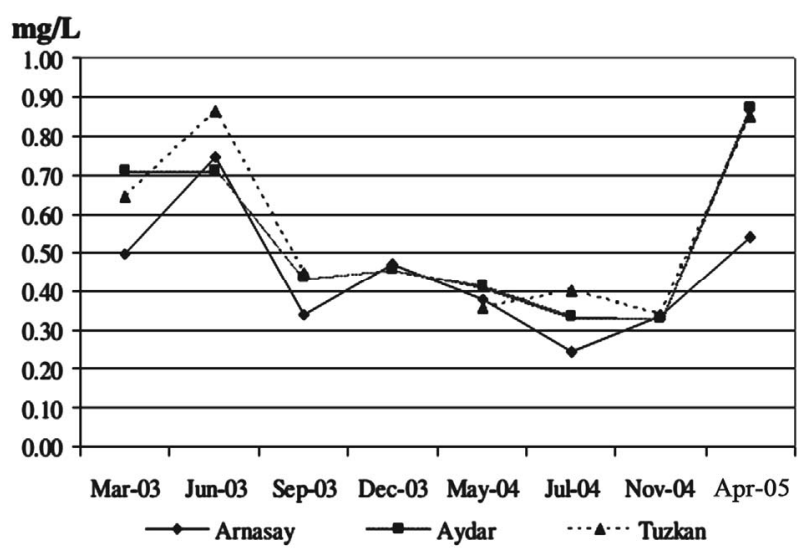

Figure 13. Dynamics of concentrations of fluorine in the water of AALS.

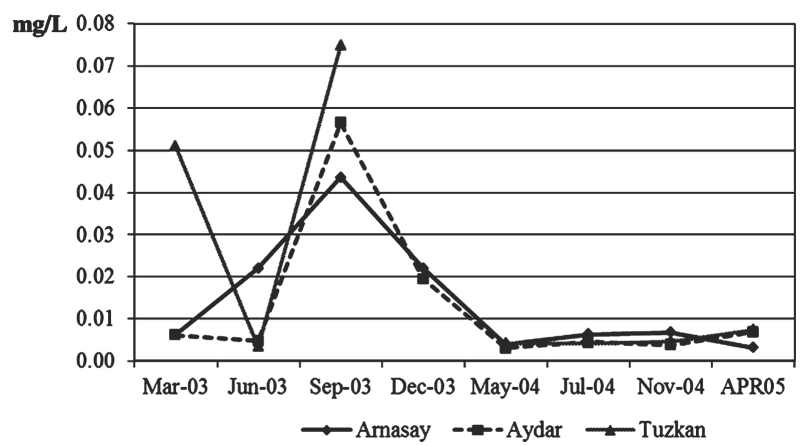

Figure 14. Dynamics of concentrations of zinc in the AALS water.

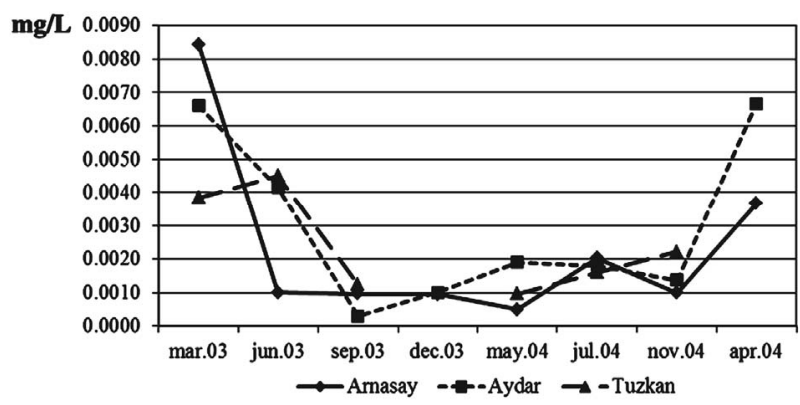

Figure 15. Dynamics of concentrations of copper in the AALS water. centration was observed in autumn and winter of 2003, and also in the spring, summer, and winter of 2004.

The MAC of copper in fish development reservoirs is $0.001 \mathrm{mg} / \mathrm{L}$. Copper concentrations in the AALS exceeded the maximum concentration limit up to 10 times. According to data $[16,17]$ the concentrations of copper, zinc and chromium in Syrdarya and Amudarya river water were as high as the MAC.

Chromium. The MAC values for $\mathrm{Cr}(\mathrm{VI})$ and $\mathrm{Cr}(\mathrm{III})$ are $0.001 \mathrm{mg} / \mathrm{L}$ and $0.5 \mathrm{mg} / \mathrm{L}$, respectively. The chromium concentrations in all parts of the AALS fluctuated uniformly between zero and $0.0087 \mathrm{mg} / \mathrm{L}$ (Figure 16).

Chromium concentrations increased in the autumn of 2003 and in the summer of 2004. In some cases chromium concentration $\mathrm{Cr}$ (VI) exceeded the normal range by a factor of 3 to 4 especially in the spring. Chromium is an industrial pollutant; and the maximum concentration limit for fish development in reservoirs is equal to $0.005 \mathrm{mg} / \mathrm{L}$. The concentrations of HMs in the AALS water, as a whole are within limits, admissible for fish industry water reservoirs. For some metals, however, such as zinc, copper and chromium the concentration was unusually high at certain times. When comparing the total concentrations of HMs with their MAC values, it was observed that the limit for zinc is temporarily exceeded 4 - 7 times, the one for copper 10 times, the one for chromium 3 - 4 times. However, the national MAC limit does not consider the speciation of HMs. Therefore, the sum of the concentrations of HMs in the suspended solid and liquid phases was taken when comparing the values with the MAC limit of HMs. This may overstate the problem of HM considerably.

\subsubsection{Additional Results of Investigations in 2011}

Concentration of main ions. Data on physico-chemical characteristics of AALS water obtained in the 2011 campaign are shown in Table 8. Differences in the concentrations of species in the lakes' water are connected with the choice of sampling points. In particular, in the western Arnasay water samples have been taken close to Aydar Lake. Upper Arnasay lake water samples have

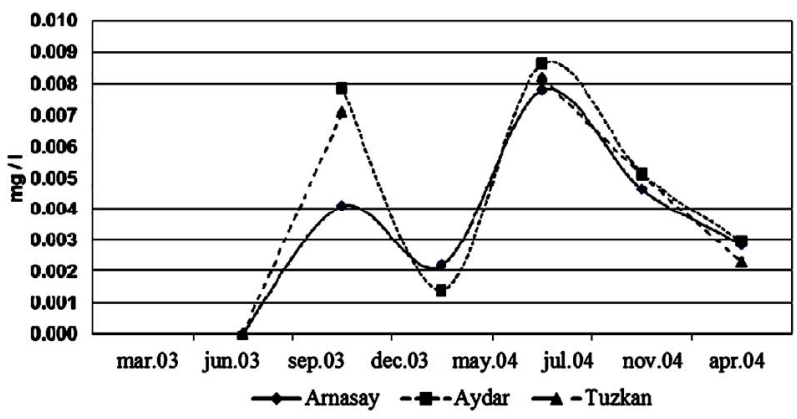

Figure 16. Dynamics of concentrations of chromium in the AALS water. 
Table 8. Physical and chemical characteristics of AALS water.

\begin{tabular}{|c|c|c|c|}
\hline Physic-chemical characteristics & Western Arnasay 12.05.11 & Upper Arnasay 12.05.11 & Tuzkan 9.05.11 \\
\hline Suspended solids, mg/L & 3.0 & 2.1 & 6.2 \\
\hline Mineralization, $\mathrm{mg} / \mathrm{L}$ & 6636.0 & 2369.0 & 6974.0 \\
\hline Chlorides, $\mathrm{mg} / \mathrm{L}$ & 1305.0 & 255.0 & 1007.0 \\
\hline Sulphate, $\mathrm{mg} / \mathrm{L}$ & 3845.0 & 706.0 & 3668.0 \\
\hline Hydrogencarbonate, $\mathrm{mg} / \mathrm{L}$ & 136.0 & 119.0 & 165.0 \\
\hline $\mathrm{Na}, \mathrm{K}, \mathrm{mg} / \mathrm{L}$ & 1460.0 & 270.0 & 1345.0 \\
\hline $\mathrm{Ca}, \mathrm{mg} / \mathrm{L}$ & 458.0 & 226.0 & 396.0 \\
\hline Magnesium, mg/L & 429.0 & 92.7 & 385.0 \\
\hline Ammonium nitrogen, $\mathrm{mg} \mathrm{N} / \mathrm{L}$ & 0.02 & 0.01 & 0.05 \\
\hline Nitrite nitrogen, $\mathrm{mg} \mathrm{N} / \mathrm{L}$ & 0.009 & 0.007 & 0.031 \\
\hline Nitrate nitrogen, mg N/L & 0.19 & 0.10 & 1.58 \\
\hline Silicon, $\mathrm{mg} / \mathrm{L}$ & 0.99 & 1.06 & 2.25 \\
\hline Iron, $\mathrm{mg} / \mathrm{L}$ & 0.05 & 0.06 & 0.04 \\
\hline Copper, $\mu \mathrm{g} / \mathrm{L}$ & 2.76 & 2.89 & 3.73 \\
\hline Zinc, $\mathrm{mg} / \mathrm{L}$ & 2.08 & 2.02 & 2.79 \\
\hline Chromium $(+6), \mathrm{mg} / \mathrm{L}$ & 0.1 & 0.06 & 0.07 \\
\hline Chromium total, $\mathrm{mg} / \mathrm{L}$ & 0.6 & 0.8 & 1.0 \\
\hline Phenol, mg/L & 0.008 & 0.008 & 0.007 \\
\hline Fluorine, mg/L & 0.42 & 0.50 & 0.35 \\
\hline Cyanides, mg/L & 0.001 & 0 & 0 \\
\hline
\end{tabular}

been taken closer to Chardara reservoir and consequently their composition sharply differs from water of Western Arnasay and Tuzkan. Mineralization of Western Arnasay water and Tuzkan lake water are approximately identical whereas Western Arnasay mineralization is comparatively low $(2369 \mathrm{mg} / \mathrm{L})$ and close to the mineralization of Chardara reservoir water [1]. Also, contents of chlorides, sulfate, hydrogen carbonate, sodium, potassium, calcium and magnesium in Western Arnasay lake and Tuzkan lake are approximately identical. The concentrations of the same species in the upper Arnasay are much lower and closer to water of the middle reaches of the Syrdarya river $[16,17]$. Concentrations of $\mathrm{Na}, \mathrm{K}, \mathrm{Ca}, \mathrm{Mg}$ and $\mathrm{Cl}$, $\mathrm{SO}_{4}, \mathrm{HCO}_{3}$ are approximately equal in western Arnasay and Tuzkan lakes, whereas in upper Arnasay lake their concentration are much lower. Concentration of silica in comparison is higher in Tuzkan lake water which is connected to discharge of collector-drainage water from irrigated lands. A similar situation is observed for anions like chloride, sulphate and hydrogen carbonate. The concentration of fluorine is approximately equal in all lakes, except Tuzkan lake. Cyanides are found only in western Arnasay lake water. The concentration of phenol is also approximately identical for all lakes.

Concentrations of nutrients. Concentrations of ammonium nitrogen, nitrite nitrogen and nitrate nitrogen in Tuzkan lake water are 2 - 3 times higher in comparison to the other lakes. Especially the concentration of nitrate nitrogen in Tuzkan lake water is $10-15$ times above that of the other lakes. This is due to the fact that Tuzkan is connected with the inflow of CDW from irrigated lands of Syrdarya and Djizak provinces. It is known that for cultivation of cotton, nitrogen and phosphorous fertilizers are used in large quantities [1]. Comparison of the hydro-chemical data of 2004-2005 and 2011 reveals some changes in the temporal distribution of concentrations of chemical substances. As mentioned above, the water level in AALS fluctuates depending on water inflow from Chardara reservoir and evaporation. These factors strongly influence the concentrations of the species measured in AALS water.

\section{1) Heavy metals}

Iron. Concentration of iron in all lakes is practically identical. It is noted that concentration iron in Tuzkan 
lake water is insignificantly low $(0.04 \mathrm{mg} / \mathrm{L})$. It is known that iron is an easily hydrolyzed element and basically migrates in undissolved form. Therefore, the main quantity of iron is undissolved and iron precipitated in Chardara reservoir.

Copper. Concentration of copper exceeds the MAC limit 2 - 3 times. Rather high concentration of copper found In Tuzkan lake water is connected to CDW from the irrigated lands of Syrdarya and Dzhizak provinces.

Zinc. Concentration of zinc is the same in western and upper Arnasay lake. While a higher value is characteristic of Tuzkan lake water which also receives CDW.

Chromium. Concentration of $\mathrm{Cr}-6$ is approximately the same in all lake waters. So are the values of total chromium $\left(\mathrm{Cr}^{3+}\right.$ and $\left.\mathrm{Cr}^{6+}\right)$. The authors of [17] compared the total concentrations of heavy metals with their MAC values. They found that $\mathrm{Hg}, \mathrm{Cd}, \mathrm{Zn}, \mathrm{Cr}$, and $\mathrm{Fe}$ exceeded the limits in the Syrdarya and Amudarya rivers water. Specifically the concentrations of $\mathrm{Zn}, \mathrm{Cr}$, and Fe exceed the MAC limit by 5 - 7 times in Chinaz (middle reach of Syrdarya river), water sampling points. Apparently, arid climate conditions and alkaline reaction of soil and rock are characteristics promoting rather high mobility of $\mathrm{Hg}$, $\mathrm{Zn}, \mathrm{Cd}, \mathrm{Sb}, \mathrm{Cr}$ and other elements in the rivers' and lakes' water of the arid zone. Also, pollution of the Syrdarya river water is the result of discharges of collector drainage water (CDW) from the irrigated lands of four provinces (Namangan, Fergana, Andijan and Tashkent) of Uzbekistan with agricultural orientation. As cited above, for cultivation of cotton, wheat and other agricultural crops phosphoric and nitrogen fertilizers containing relatively high residual quantities of heavy metals were widely used in Uzbekistan, especially in the period of Soviet Union ruling [1]. Thus it is possible to confirm that the basic sources of entry of HMs in AALS are the Syrdarya river water and CDW from irrigated lands. It is necessary to include to the national system of monitoring a wider range of heavy metals, such as $\mathrm{Hg}$, $\mathrm{Sb}, \mathrm{As}, \mathrm{Cd}, \mathrm{Se}$ and others, which possess cancerogenic, mutagenic and cumulative negative effects.

\section{2) Fishery in AALS}

Today, AALS is one of the largest and most important fish reservoirs of Uzbekistan. In the late eighties of last century, AALS annually produced more than 4000 tons of different species of fish. That was more than half of the fish harvest in the country [9-11]. In recent years these indicators have considerably decreased. In 2006 only 924 tons of fish were produced. It is very important to solve problems related to fish industry to eliminate the deficiency of fish products in the local market. In Table 9 a list of fish species present in AALS is given.

As shown in Table 9, there are 18 kinds of fish inhabiting AALS. Out of them 16 species have commercial value and 8 of them are aboriginal. In Table 10, the gen- eral structure of fish harvesting from AALS is given. Ichthyology material was collected with the help of steel nets from 30 to $100 \mathrm{~mm}$ mesh width. Gathering and processing of ichthyology material was carried out by methods discussed in [9].

The fish harvesting is dominated by carp, roach, pike perch, crucian carp and asps. Probably, because of change of quality and quantity of AALS water since 2007, some species of fish have disappeared and there are new species appearing like angel fish and snakehead. The analysis of long term data on fish harvesting in AALS shows that the change of water level negatively influences quantity and species of harvested fish. Species such as the white cupid, the white silver carp and the multi-colored silver carp have gradually disappeared. The increased mineralization in AALS has resulted in the disappearance of pike which is very sensitive to mineralization. This fact is extremely important for fish development of the AALS ecosystem. While it is possible to plan the size of the lake by designing the diversions of water from Chardara reservoir, it is much more difficult to influence water quality.

\section{Conclusions}

The AALS water quality and quantity in various seasons during 2003-2005 and 2009-2011 were studied for the purpose of development of fishery industry. Generally the water quality is sufficient. The following improvements to the current situation could be the first step towards a management concept for the AALS: 1) To prevent sharp increase of mineralization of AALS water and to support the present water level, an annual feed of the lake system derived from Syradarya river through Chardara reservoir of $2.5-2.6 \mathrm{~km}^{3} / \mathrm{a}$ is necessary on top of the water input of close to $2.5 \mathrm{~km}^{3} / \mathrm{a}$ arriving in the form of dumped CDW. 2) At a water level of $245 \mathrm{~m}$ asl (absolute sea level), flooding of the irrigated lands does not occur. However, as a result of an increase in ground water table, the condition of irrigated lands with respect to water logging and salinization worsens considerably. Further increase in water table up to $250 \mathrm{~m}$ asl may cause a direct flooding of the irrigated lands to the south of Tuzkan lake. As a whole, the ecological condition of the AALS can be regarded as favorable for fishery development and ecotourism. Under these circumstances it is necessary to improve the system of monitoring the ecological state of water bodies using a stationary observation network, integrated research expeditions, using modern equipment and observation techniques including remote sensing and satellite information. Use of a hydrological modeling approach for forecasting quantity and quality of AALS water resources is also important. Finally, research on eutrophication and means of control 
Table 9. List of species of fish present in AALS.

\begin{tabular}{|c|c|c|c|c|}
\hline Species of fishes & Commercial & Non-commercial & Aboriginal & Delivered \\
\hline Carp & + & & + & \\
\hline Pikeperch & + & & & + \\
\hline Asp & + & & & \\
\hline sheatfish & + & & + & \\
\hline Grasscarp & + & & & + \\
\hline Silvercarp & + & & & + \\
\hline Motley silver carp & + & & & + \\
\hline Roach & + & & + & \\
\hline Cruciancarp & + & & & + \\
\hline Eastbream & + & & + & \\
\hline Snakehead & + & & & \\
\hline Royalfish & + & & + & \\
\hline Sabrefish & + & & + & \\
\hline White-eye & + & & + & \\
\hline Pike & + & & + & \\
\hline \multicolumn{5}{|l|}{ Aralbarbel } \\
\hline Sawbelly & + & + & & \\
\hline
\end{tabular}

Table 10. The general structure of catch (the general quantity in \%).

\begin{tabular}{|c|c|c|}
\hline \multirow{2}{*}{ Years } & \multicolumn{2}{|r|}{ Fish species catch, in \% } \\
\hline & Tons & $\%$ \\
\hline 2004 & 702.8 & Carp-17.60\%, Roach-45.26\%, Pike perch-8.78\%, Crucian carp-10.81\%, Others- $17.55 \%$. \\
\hline 2005 & 963.9 & Carp-12.8\%, Roach-65.0\%, Pike perch-2.4\%, Crucian carp-11.5\%, Others-8.3\%. \\
\hline 2006 & 924.3 & Carp-11.8\%, Roach $-50.3 \%$, Pike perch $-6.6 \%$, Asp $-1.9 \%$, Crucian carp- $17.2 \%$, Bream $-6.4 \%$, Others $-4.1 \%$. \\
\hline 2007 & 1299.0 & Carp-13.4\%, Roach $-41.0 \%$, Pike perch-3.1\%, Crucian carp-19.3\%, Others-23.2\%. \\
\hline 2008 & 1726.2 & Carp-11.42\%, Roach-46.38\%, Pike perch-6.11\%, Crucian carp-16.39\%, Others- $19.67 \%$. \\
\hline 2009 & 1776.5 & Carp $-15.80 \%$, Roach $-20.68 \%$, Asp $-1.1 \%$, Pike perch $-17.94 \%$, Crucian carp $-0.5 \%$, White Amur bream-2.36\%. \\
\hline 2010 & 2039.4 & Carp $-17.73 \%$, Roach $-47.78 \%$, Pike perch $-23.71 \%$, Crucian carp- $8.58 \%$, Snakehead $-0.93 \%$, Others- $1.26 \%$. \\
\hline
\end{tabular}

in AALS is necessary. Today, the existence of AALS is necessary for both the Republic of Uzbekistan and the Republic of Kazakhstan. In this connection, to allow allocation of additional water resources from Syrdarya river basin to prevent sharp increase of mineralization and to control the water level in AALS at the prsent level, it is necessary to give AALS the status of "International protected territory", having socio-economic, ecological and fish industry value for the given region.

\section{Acknowledgements}

The Swiss National Science Foundation is acknowledged for financing the International Short Visit to ETH Zurich, Switzerland to complete this study.

\section{REFERENCES}

[1] B. B. Alihanov, "About a Condition of Environment and Use of Natural Resources in Republic of Uzbekistan (the Retrospective Analysis for 1988-2007)," National Report of the State Committee for Nature Protection of the Republic of Uzbekistan, Chinor ENK, Tashkent, 2008.

[2] E. Kholmatov, R. Ishankulov, A. Mavlonov and I. Safarov, "Aydar-Arnasay Lakes System: Current and Future Ecological Problems," Uzbekiston Khabarnomasi, Vol. 2, 
2001, pp. 18-22. (in Russian)

[3] Report on Expedition Survey of Aydar-Arnasay Lake System in the period from 21 September to 5 October 2011, Research Center MKVK, the State Committee of Nature Protection and Institute of Zoology, The Academy of Sciences of Uzbekistan, Tashkent, 2011. (in Russian)

[4] A. Kiyatkin, I. S. Shaporenko and M. V.Sanin, "Water and Salt Regime of the Arnasai Lake," Power Technology and Engineering, Vol. 24, 1990, pp. 172-177.

[5] N. Gorelkin and A. Nikitin, "Water Balance of Arnasai Lake System," Proceedings of SARNIGMI, Vol. 39, 1976, pp. 76-93. (in Russian)

[6] Y. Kawabata, K. N. Toderich and T. Rakhimiova, "Integrated Water-Land and Plant Resources Management for Improvement Income of Rural Agro Pastoralists in the Aydarkul-Arnasay Lakes Ecosystems (AALE)," Proceedings of the International Conference dedicated to the 90th Anniversary of the National University of Uzbekistan, Tashkent, 2008, pp. 178-186.

[7] B. Kurbanov, A. Primov and I. Lesnik, "Assessment of Waterlogging processes in the Aydarkul-Arnasay Lakes Systems by Using GIS Technologies," The Ecological Bulletin, Vol. 4, 2009, pp. 22-26. (in Russian)

[8] S. Wahyuni, S. Oishi and K Sunada, "Analysis of WaterLevel Fluctuations in Aydar-Arnasay-Tuzkan Lake System and Its Impacts on the Surrounding Groundwater Level," Annual Journal of Hydraulic Engineering, Vol. 53, 2009, pp. 37-42.

[9] N. Mullabaev, "Hydroecological Condition and Fish Economy Potential of Reservoirs of Uzbekistan on an Example of Arnasay Lakes System and Mejdurechensk Water Basin," Ph.D. Thesis, Institute of Zoology, The Academy of Sciences of Uzbekistan, Tashkent, 2011. (in Russian)

[10] N. Mullabaev, "The Arnasay Lake System Fish Product's
Development Perspectives," The Ecological Bulletin, Vol. 6, 2006, pp. 37-38. (in Russian)

[11] N. Mullabaev, "Primary Production and Decomposition of Organic Substances in the Arnasay Lake System," The Uzbek Biological Journal, Vol. 3, 2006, pp. 10-13. (in Russian)

[12] "Report on the Observation Data on Aydar-Arnasay Lake System (AALS)," Research Institute of Hydro-Meteorology, Uzbekistan, 2008. (in Russian)

[13] N. Holmatov, "Basic the Trade of Acclimatised Kind of Fishes, and Their Values in the Arnasay Lake System," Ph.D. Thesis, Institute of Zoology, The Academy of Sciences of Uzbekistan, Tashkent, 1972. (in Russian)

[14] B. Karimov, M. Schlueter, H. Blanchoud, M. Kurambaeva and N. Mullabaev, "The Use of Ecosystem Indicators for the Evaluation Data Base Construction and Computer Modeling of the State of Hydro-Ecosystems in Aral Sea Basin on Example of Arnasay Lake System," International Symposium: Quantitative Ecosystem Indicators for Fisheries Management, Paris, 31 March-3 April 2004, pp. 56-58.

[15] The Second National Communication of the Republic of Uzbekistan under the United Nations Framework Convention on Climate Change, Tashkent, 2008, 187 p.

[16] "A Year-Book of Quality of Superficial Waters in the Territory of Uzbekistan for 2002-2010," Research Institute of Hydro-Meteorology, Tashkent, 2002-2010. (in Russian)

[17] R. A. Kulmatov and M. Hojamberdiev, "Speciation Analyses of Heavy Metals in the Transboundary Rivers of Aral Sea Basin: Amudarya and Syrdarya Rivers," Journal of Environmental Science and Engineering, Vol. 4, 2010, pp. 36-45. 